\title{
SYNTHESIS AND STRUCTURE OF TETRAPHENYLANTIMONY $\beta$-ISATOXIMATE
}

\author{
E.V. Artem'eva, katriona-art@yandex.ru \\ O.K. Sharutina, sharutinao@mail.ru \\ South Ural State University, Chelyabinsk, Russian Federation
}

\begin{abstract}
( $\beta$-Isatoximato)tetraphenylantimony (1) was obtained by the reaction of pentaphenylantimony with $\beta$-isatoxime. X-ray diffraction analysis showed that the antimony atom in complex 1 had distorted trigonal-bipyramidal coordination..

Keywords: pentaphenylantimony, $\beta$-isatoxime, dephenylation, $(\beta$-isatoximato)tetraphenylantimony, molecular structures, $X$-ray diffraction analysis.
\end{abstract}

\section{Introduction}

It is known from the literature sources that pentaarylantimony reacts with inorganic and organic acids $\mathrm{HX}\left(\mathrm{X}=\mathrm{OR}, \mathrm{OAr}, \mathrm{OSO}_{2} \mathrm{R}, \mathrm{OC}(\mathrm{O}) \mathrm{R}, \mathrm{Hal}, \mathrm{NO}_{3}\right)$ to form antimony derivatives $\mathrm{Ar}_{4} \mathrm{SbX}$ in high yield [1-6]. In some articles the dephenylation of pentaphenylantimony was studied in the reaction with oximes [7-10], leading to formation of tetraphenylantimony oximes. It has been found that when ketoximes are used, the separation of two phenyl groups and the formation of triphenylantimony dioximates are sometimes observed [7].

Another method for the preparation of tetraaryl antimony oxymates is based on a substitution reaction with the use of tetraarylantimony halides. Thus, $\mathrm{Ar}_{4} \mathrm{SbX}$ derivatives were synthesized $(\mathrm{Ar}=\mathrm{Ph}$, 4- $\left.\mathrm{ClC}_{6} \mathrm{H}_{4}\right)$ by the reaction of tetraarylantimony bromide with $\mathrm{N}$-hydroxy-demethylcantharimide with the addition of $\mathrm{Et}_{3} \mathrm{~N}$; the reaction products were characterized by IR and NMR spectroscopy methods [11]. Similarly, organoantimony arylhydroxamates of the general formula $\left(4-\mathrm{CH}_{3} \mathrm{C}_{6} \mathrm{H}_{4}\right)_{4} \mathrm{SbX}$ were synthesized, the structure of the compounds thus obtained was established by the X-ray diffraction method [12]. By the means of MTT and SRB, it was found that those compounds had antitumor effect $[11,12]$.

Tetraarylantimony oximates were obtained in high yield as a result of a ligand redistribution reaction of pentaphenyl- and penta( $p$-tolyl)antimony with triarylantimony dioximates $[7,13]$.

According to X-ray diffraction analysis data, antimony atoms in tetraaryl antimony oximates, as a rule, have distorted trigonal-bipyramidal coordination with the iminoxy group oxygen atom in the axial position. Short distances between the iminoxy group nitrogen atom and the antimony atom are observed [7-10,13].

The present paper describes further study of the interaction of pentaphenylantimony with oximes, in particular, $\beta$-isatoxime, and the establishment of the molecular structure of the obtained product.

\section{Experimental}

Synthesis of $\beta$-isatoximato tetraphenylantimony (1)

a) $300 \mathrm{mg}$ of pentaphenylantimony $(0.59 \mathrm{mmol})$ and $96 \mathrm{mg}(0.59 \mathrm{mmol})$ of $\beta$-isatoxime were dissolved in benzene, sealed in an ampoule and heated for several hours in a water bath until the precipitate dissolved. The mixture was held for several days at $20^{\circ} \mathrm{C}$. After removing the solvent, the solid residue was recrystallized from chloroform with addition of heptane. Yellow crystals with the mass of $0.348 \mathrm{~g}$ (99\%) and melting point of $193{ }^{\circ} \mathrm{C}$ were obtained.

IR spectrum, $v \mathrm{~cm}^{-1}: 3148,3065,1705,1612,1591,1551,1508,1474,1458,1435,1375,1340$, 1296, 1291, 1182, 1151, 1096, 1057, 1020, 997, 972, 785, 754, 729, 692, 650, 582, 492, 457, 419.

Similarly, an experiment was carried out with 1:2 molar ratio of the reactants. The solid residue was recrystallized from ethanol.

IR spectra were recorded on a Shimadzu IRAffinity-1S FTIR spectrometer (pellets with $\mathrm{KBr}$; $4000-400 \mathrm{~cm}^{-1}$ ).

X-ray diffraction analysis of crystalline substance 1 was performed on a Bruker D8 QUEST automatic four-circle diffractometer (Mo K $\alpha^{-}$emission, $\lambda=0.71073 \AA$, graphite monochromator). 
Data collection and editing, unit-cell parameters refinement, and correction for absorption were carried out in SMART and SAINT-Plus software. All calculations aimed at solving and refining the structure of compound 1 were performed in SHELXL/PC software [14, 15]. Structure 1 was determined by direct methods and refined with LS method in the anisotropic approximation for non-hydrogen atoms. The selected crystallographic data and the structure refinement results are listed in Table 1. Selected bond lengths and bond angles are summarized in Table 2.

The full tables of atomic coordinates, bond lengths, and bond angles were deposited with the Cambridge Crystallographic Data Centre (CCDC 1814675 for compound 1 deposit@ccdc.cam.ac.uk; http://www.ccdc.cam.ac.uk).

Crystallographic data and the experimental and structure refinement parameters for compound 1

Table 1

\begin{tabular}{|c|c|}
\hline \multirow{2}{*}{ Parameter } & Value \\
\hline & 1 \\
\hline Empirical formula & $\mathrm{C}_{64} \mathrm{H}_{50} \mathrm{~N}_{4} \mathrm{O}_{4} \mathrm{Sb}_{2}$ \\
\hline Formula weight & 1182.65 \\
\hline$T, \mathrm{~K}$ & 293.15 \\
\hline Crystal system & triclinic \\
\hline Space group & $\mathrm{P}-1$ \\
\hline$a, \AA$ & $10.106(12)$ \\
\hline$b, \AA$ & $10.340(14)$ \\
\hline$c, \AA$ & $26.82(3)$ \\
\hline$\alpha, \operatorname{deg}$ & $83.36(6)$ \\
\hline$\beta, \operatorname{deg}$ & $79.45(4)$ \\
\hline$\gamma, \operatorname{deg}$ & $84.63(7)$ \\
\hline$V, \AA^{3}$ & $2729(6)$ \\
\hline$Z$ & 2 \\
\hline$\rho_{\text {(calcd.) }}, \mathrm{g} / \mathrm{cm}^{3}$ & 1.4389 \\
\hline$\mu, \mathrm{mm}^{-1}$ & 1.042 \\
\hline$F(000)$ & 1190.0 \\
\hline Crystal size, $\mathrm{mm}$ & $0.42 \times 0.13 \times 0.1$ \\
\hline $2 \theta$ Range of data collection, deg & $5.66-49.54$ \\
\hline Range of refraction indices & $\begin{array}{l}-11 \leq h \leq 11, \\
-12 \leq k \leq 12, \\
-31 \leq l \leq 31\end{array}$ \\
\hline Reflections collected & 45577 \\
\hline Independent reflections & 9232 \\
\hline$R_{\text {int }}$ & 0.0583 \\
\hline Refinement variables & 667 \\
\hline GOOF & 1.045 \\
\hline$R$ factors for $\mathrm{F}^{2}>2 \sigma\left(\mathrm{F}^{2}\right)$ & $R_{1}=0.0973, w R_{2}=0.2376$ \\
\hline$R$ factors for all reflections & $R_{1}=0.1105, w R_{2}=0.2444$ \\
\hline $\begin{array}{l}\text { Residual electron density } \\
(\min / \max ), e / \AA^{3}\end{array}$ & $2.46 /-2.94$ \\
\hline
\end{tabular}

Selected bond lengths and bond angles in the structure of compound 1

\begin{tabular}{|c|c|c|c|}
\hline Bond & $d, \AA$ & Angle & $\omega$, deg \\
\hline $\mathrm{Sb}(1)-\mathrm{C}(1)$ & $2.128(13)$ & $\mathrm{C}(11) \mathrm{Sb}(1) \mathrm{O}(1)$ & $177.9(4)$ \\
\hline $\mathrm{Sb}(1)-\mathrm{C}(21)$ & $2.115(12)$ & $\mathrm{C}(1) \mathrm{Sb}(1) \mathrm{C}(21)$ & $112.9(5)$ \\
\hline $\mathrm{Sb}(1)-\mathrm{C}(31)$ & $2.116(13)$ & $\mathrm{C}(1) \mathrm{Sb}(1) \mathrm{C}(31)$ & $117.2(5)$ \\
\hline $\mathrm{Sb}(1)-\mathrm{O}(1)$ & $2.231(9)$ & $\mathrm{C}(21) \mathrm{Sb}(1) \mathrm{C}(31)$ & $108.5(7)$ \\
\hline $\mathrm{Sb}(1)-\mathrm{C}(11)$ & $2.167(12)$ & $\mathrm{N}(1) \mathrm{O}(1) \mathrm{Sb}(1)$ & $112.7(11)$ \\
\hline $\mathrm{O}(1)-\mathrm{N}(1)$ & $1.331(14)$ & $\mathrm{O}(1) \mathrm{N}(1) \mathrm{C}(41)$ & $81.1(4)$ \\
\hline $\mathrm{N}(1)-\mathrm{C}(41)$ & $1.330(16)$ & $\mathrm{C}(1) \mathrm{Sb}(1) \mathrm{O}(1)$ & \\
\hline
\end{tabular}


Химия элементоорганических соединений

Table 2 (end)

\begin{tabular}{|c|c|c|c|}
\hline Bond & $d, \AA$ & Angle & $\omega$, deg \\
\hline $\mathrm{O}(2)-\mathrm{C}(42)$ & $1.206(16)$ & $\mathrm{C}(21) \mathrm{Sb}(1) \mathrm{O}(1)$ & $85.5(4)$ \\
\hline $\mathrm{N}(2)-\mathrm{C}(42)$ & $1.388(17)$ & $\mathrm{C}(31) \mathrm{Sb}(1) \mathrm{O}(1)$ & $83.2(4)$ \\
\hline $\mathrm{Sb}(2)-\mathrm{C}(51)$ & $2.122(14)$ & $\mathrm{C}(81) \mathrm{Sb}(2) \mathrm{O}(3)$ & $168.1(6)$ \\
\hline $\mathrm{Sb}(2)-\mathrm{C}(61)$ & $2.122(14)$ & $\mathrm{C}(51) \mathrm{Sb}(2) \mathrm{C}(61)$ & $121.4(6)$ \\
\hline $\mathrm{Sb}(2)-\mathrm{C}(71)$ & $2.103(18)$ & $\mathrm{C}(51) \mathrm{Sb}(2) \mathrm{C}(71)$ & $115.3(7)$ \\
\hline $\mathrm{Sb}(2)-\mathrm{O}(3)$ & $2.195(11)$ & $\mathrm{C}(61) \mathrm{Sb}(2) \mathrm{C}(71)$ & $120.8(6)$ \\
\hline $\mathrm{Sb}(2)-\mathrm{C}(81)$ & $2.179(14)$ & $\mathrm{N}(3) \mathrm{O}(3) \mathrm{Sb}(2)$ & $127.5(11)$ \\
\hline $\mathrm{O}(3)-\mathrm{N}(3)$ & $1.300(18)$ & $\mathrm{O}(3) \mathrm{N}(3) \mathrm{C}(91)$ & $111.0(15)$ \\
\hline $\mathrm{N}(3)-\mathrm{C}(91)$ & $1.33(2)$ & $\mathrm{C}(51) \mathrm{Sb}(2) \mathrm{O}(3)$ & $87.4(5)$ \\
\hline $\mathrm{O}(4)-\mathrm{C}(92)$ & $1.21(2)$ & $\mathrm{C}(61) \mathrm{Sb}(2) \mathrm{O}(3)$ & $74.9(5)$ \\
\hline $\mathrm{N}(4)-\mathrm{C}(92)$ & $1.36(2)$ & $\mathrm{C}(71) \mathrm{Sb}(2) \mathrm{O}(3)$ & $92.3(6)$ \\
\hline
\end{tabular}

\section{Results and Discussion}

We have studied the reactions of pentaphenylantimony with $\beta$-isatoxime containing a large organic radical with several functional groups. It has been found that, regardless of the molar ratio of the reactants $(1: 1$ or $1: 2)$, the reaction product is ( $\beta$-isatoximato)tetraphenylantimony:<smiles>O=C1Nc2ccccc2/C1=N\O[SbH2]c1ccccc1</smiles>

Compound $\mathbf{1}$ is a crystalline substance, highly soluble in aromatic and aliphatic hydrocarbons, resistant to the air moisture and oxygen.

The resulting compound has been studied by IR spectroscopy and X-ray diffraction analysis.

In the IR spectrum of compound 1 there are absorption bands at 3148 and $3065 \mathrm{~cm}^{-1}$, characterizing the presence of the $\mathrm{N}-\mathrm{H}$ bond, and a band at $1705 \mathrm{~cm}^{-1}$, which appears as a result of valence vibrations of the $\mathrm{C}=\mathrm{O}$ bond. Characteristic bands are observed at $1551 \mathrm{~cm}^{-1}(\mathrm{C}=\mathrm{N}$ bond $), 1020 \mathrm{~cm}^{-1}(\mathrm{~N}-\mathrm{O}$ bond $)$. In comparison with the initial oxime spectrum, the absorption bands in the spectrum of compound 1 are shifted to longer wavelengths. Vibrations at $419 \mathrm{~cm}^{-1}$ indicate the presence of the $\mathrm{Sb}-\mathrm{C}$ bond in the molecule of compound $\mathbf{1}$ [16].

According to the X-ray diffraction analysis data, in the crystal of compound $\mathbf{1}$ there are two crystallographically independent molecules $(\boldsymbol{a}$ and $\boldsymbol{b})$. Antimony atoms have distorted trigonal-bipyramidal coordination with the iminoxy group oxygen atom and the carbon atom of one of phenyl groups in the axial positions (Fig. 1).

The $\mathrm{SbC}_{3}$ fragment lying in the equatorial plane is not flat. The $\mathrm{Sb}$ atom deviates from the $\left[\mathrm{C}_{3}\right]$ plane by $0.246 \AA(\boldsymbol{a})$ and $0.198 \AA(\boldsymbol{b})$ toward the axial carbon atom. The sums of the valence angles of $\mathrm{C}_{\mathrm{eq}} \mathrm{SbC}_{\mathrm{eq}}$ in the equatorial planes are $356.0(5)^{\circ}$ (a) и $357.5(6)^{\circ}(\boldsymbol{b})$, the values of the individual angles differ from the theoretical $120^{\circ}$ by not more than $7.1^{\circ}$. The axial angle $\mathrm{OSbC}_{\mathrm{ax}}$ is $177.9(4)^{\circ}(\boldsymbol{a})$ and $168.1(6)^{\circ}(b)$. The values of the angles $\mathrm{C}_{\mathrm{ax}} \mathrm{SbC}_{\mathrm{eq}}$ and $\mathrm{C}_{\mathrm{eq}} \mathrm{SbO}$ lie within the limits of $92.4(5)^{\circ}-100.0(5)^{\circ}$ $(\boldsymbol{a}), 93.5(6)^{\circ}-97.0(6)^{\circ}(\boldsymbol{b})$ and $81.1(4)^{\circ}-85.5(4)^{\circ}(\boldsymbol{a}), 74.9(5)^{\circ}-92.3(6)^{\circ}(\boldsymbol{b})$, respectively, which differs from the theoretical value of $90^{\circ}$ and is caused by the deviation of the $\mathrm{Sb}$ atom from the equatorial plane.

The variation intervals of the $\mathrm{Sb}-\mathrm{C}_{\mathrm{eq}}$ bond lengths are $2.115(12)-2.128(13) \AA(a), 2.103(18)$ 2.122(14) $\AA(\boldsymbol{b})$. The axial bonds Sb-C (2.167(12) $\AA(\boldsymbol{a}), 2.179(14) \AA(\boldsymbol{b}))$ are considerably longer than the equatorial bonds. The distances Sb-O (2.231(9) $\AA(\boldsymbol{a}), 2.195(11) \AA(\boldsymbol{b}))$ significantly exceed the sum of the covalent radii of $\mathrm{Sb}$ and $\mathrm{O}$ atoms (2.07 $\AA$ [17]), as well as the distance between the $\mathrm{Sb}$ atom and the axial $\mathrm{C}$ atom, similarly, as in other compounds, where the $\mathrm{O}-\mathrm{N}=\mathrm{C}$ fragment is linked to electronaccepting functional groups [18-20]. Interestingly, the $\mathrm{Sb}-\mathrm{O}$ distances $(2.121(4)-2.179(1) \AA)$ in previously studied tetraphenylantimony oximates, containing electron-donating substituents, are smaller than those in compound 1 and do not exceed the $\mathrm{Sb}-\mathrm{C}_{\mathrm{ax}}$ distances $(2.167(8)-2.207(1) \AA)$ [8-10]. 


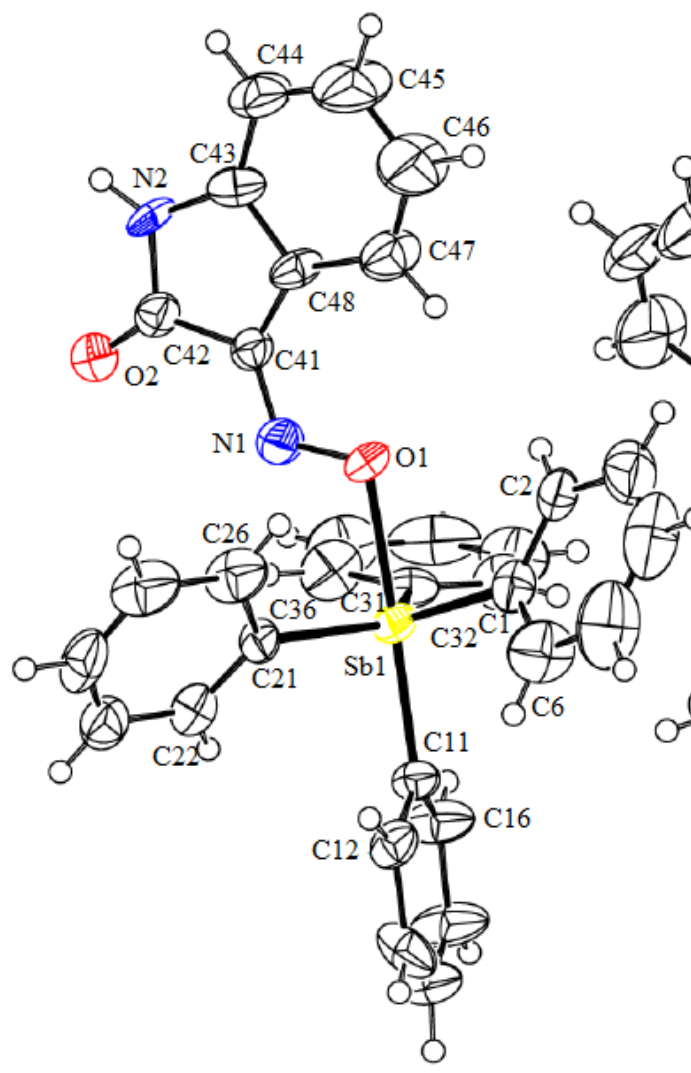

a)

b)

Fig. 1. The structure of compound $1(a, b)$

In the molecules $\boldsymbol{a}$ and $\boldsymbol{b}$, the intramolecular contacts $\mathrm{Sb} \cdots \mathrm{N}$ are observed. The distances between the $\mathrm{Sb}$ atom and the iminoxy-group $\mathrm{N}$ atom $\mathrm{Sb} \cdots \mathrm{N}[2.94(1) \AA(\boldsymbol{a}), 3.16(2) \AA(\boldsymbol{b})]$ are shorter than the sum of van der Waals radii of these atoms $(3.8 \AA$ [17]). The reduction of the distances $\mathrm{Sb} \cdots \mathrm{N}$ is accompanied by the decrease of the SbON angle values $\left(108.5(7)^{\circ}(\boldsymbol{a}), 127.5(11)^{\circ}(\boldsymbol{b})\right)$, the SbON angle in molecule $\boldsymbol{b}$ is abnormally large, in comparison with the corresponding value in analogous compounds $\left(102.7(4)^{\circ}-109.81(7)^{\circ}\right)[8-10]$. The values of the ONC angles in the molecules are close: $113(1)^{\circ}(\boldsymbol{a})$, $111(1)^{\circ}(b)$. No dependence in the change of the $\mathrm{O}-\mathrm{N}$ and $\mathrm{N}-\mathrm{C}$ bond lengths $(1.331(14) \AA, 1.330(16) \AA$ (a) and 1.300(18) $\AA, 1.33(2) \AA(b))$ is observed.

In the condensed heterocycle in molecule $\boldsymbol{a}$, the iminoxy group is located in the heterocycle plane, while in molecule $\boldsymbol{b}$ the $\mathrm{O}$ atom deviates from the plane by $0.308 \AA$ and the $\mathrm{N}$ atom deviates by $0.192 \AA$. The angles between the heterocycle plane and the plane of the benzene ring are $3.50^{\circ}(\mathrm{a})$ and $6.02^{\circ}(\mathrm{b})$.

\section{Conclusions}

Thus, regardless of the molar ratio of the reactants, as a result of the reaction of pentaphenylantimony with $\beta$-isatoxime, ( $\beta$-isatoximato)tetraphenylantimony is formed. In spite of the fact that $\beta$-isatoxime contains several different functional groups (the amino- and the keto-group), it reacts with pentaphenylantimony in a conventional manner. The antimony atom in the resulting compound has distorted trigonal-bipyramidal coordination with the iminoxy-group oxygen atom and the carbon atom of one of the phenyl groups.

\section{Acknowledgments}

We are grateful to V.V. Sharutin for the X-ray diffraction analysis of complex $\mathbf{1}$. 


\section{References}

1. Schmidbaur H., Mitschke K.H. Hydrogendicarboxylat-Ionen als Wasserstoffbrückenverknüpfte Chelatsysteme in Organoantimonverbindungen. Angew. Chem., 1971, vol. 83, no. 4, pp. 149-150. DOI: 10.1002/ange.19710830414.

2. Sharutin V.V., Senchurin V.S., Sharutina O.K., Panova L.P. Adducts of Tetraphenylstibium Nitrate with Nitric Acid and of Tetraphenylstibium Acetate with Acetic Acid: Syntheses and Structures. Rus. J. Inorg. Chem., 2008, vol. 53, no. 7, pp. 1110-1114. DOI: 10.1134/S0036023608070206.

3. Sharutin V.V., Sharutina O.K., Bondar' E.A., Subacheva O.V., Pakusina A.P., Gerasimenko A.V., Sergienko S.S. Synthesis and Structure of (4-Acetyl-3-hydroxyphenoxy)tetraphenylantimony. Rus. J. Gen. Chem., 2003, vol. 73, no. 3, pp. 350-353. DOI: 10.1023/A:1024993400389.

4. Sharutin V.V., Pakusina A.P., Egorova I.V., Platonova T.P., Gerasimenko A.V., Gerasimenko E.A., Zakharov L.N., Fukin G.K. Synthesis and Structure of Tetraphenylstibonium and Tetraphenylphosphonium Hydrogen Sulfates. Rus. J. Gen. Chem., 2003, vol. 73, no. 4, pp. 536-540. DOI: 10.1023/A:1025676100508.

5. Sharutin V.V., Sharutina O.K., Pakusina A.P., Platonova T.P., Gerasimenko A.V., Bukvetskii B.V., Pushilin M.A. Synthesis and Structure of Tetra- and Triphenylantimony Organosulfonates. Rus. J. Coord. Chem., 2004, vol. 30, no. 1, pp. 13-22. DOI: 10.1023/B:RUCO.0000011636.28262.d3.

6. Sharutin V.V., Sharutina O.K., Senchurin V.S. Tetraphenylantimony Aroxides $\mathrm{Ph}_{4} \mathrm{SbOAr}(\mathrm{Ar}=$ $\mathrm{C}_{6} \mathrm{H}_{4} \mathrm{C}_{6} \mathrm{H}_{7}, \mathrm{C}_{6} \mathrm{H}_{2}\left(\mathrm{Br}_{2}-2,6\right)($ tert- $\left.\mathrm{Bu}-4), \mathrm{C}_{6} \mathrm{H}_{3}\left(\mathrm{NO}_{2}\right)_{2}-2,4, \mathrm{C}_{6} \mathrm{H}_{2}\left(\mathrm{Br}_{2}-2,6\right)\left(\mathrm{NO}_{2}-4\right)\right)$ : Synthesis and Structure. Rus. J. Inorg. Chem., 2017, vol. 62, no. 3, pp. 295-300. DOI: 10.1134/S0036023617030147.

7. Sharutin V.V., Sharutina O.K., Molokova O.V., Pakusina A.P., Gerasimenko A.V., Sergienko A.S., Bukvetskii B.V., Popov D.Yu. Synthesis and Structures of Tetra-and Triarylantimony Oximates. Rus. J. Coord. Chem., 2002, vol. 28, no. 8, pp. 544-553. DOI: 10.1023/A:1019701511840.

8. Sharutin V.V., Molokova O.V., Sharutina O.K., Akimova T.I., Gerasimenko A.V., Pushilin M.A. Synthesis and Structure of Tetraphenylantimony Oximates $\mathrm{Ph}_{4} \mathrm{SbON}=\mathrm{CRR}^{\prime}\left(\mathrm{CRR}^{\prime}=\mathrm{C}_{6} \mathrm{H}_{9}-\mathrm{C}_{6} \mathrm{H}_{9}-2\right.$ and $\left.\mathrm{R}=\mathrm{Ph}, \mathrm{R}^{\prime}=\mathrm{C}(\mathrm{O}) \mathrm{Ph}\right)$. Rus. J. Coord. Chem., 2004, vol. 30, no. 8, pp. 559-565. DOI: 10.1023/B:RUCO.0000037435.99654.0a.

9. Sharutin V.V., Sharutina O.K., Molokova O.V. Synthesis and Structure of Tetra- and Triphenylantimony Salicylaldoximates. Rus. J. Inorg. Chem., 2012, vol. 57, no. 6, pp. 832-837. DOI: 10.1134/S0036023612010226.

10. Sharutin V.V., Sharutina O.K. Syntheses and Structures of Tetraphenylantimony Oximates: $\mathrm{Ph}_{4} \mathrm{SbON}=\mathrm{CHR}\left(\mathrm{R}=\mathrm{C}_{6} \mathrm{H}_{4} \mathrm{Br}-2, \mathrm{C}_{6} \mathrm{H}_{4} \mathrm{NO}_{2}-2, \mathrm{C}_{4} \mathrm{H}_{3} \mathrm{~S}\right)$. Rus. J. Coord. Chem., 2017, vol. 43, no. 4, pp. 232-237. DOI: 10.1134/S1070328417040054.

11. Wang G.-C., Xiao J., Yu L., Li J.-Sh., Cui J.-R., Wang R.-Q., Ran F.-X. Synthesis, Crystal Structures and in vitro Antitumor Activities of Some Arylantimony Derivatives of Analogues of Demethylcantharimide. J. Organomet. Chem., 2004, vol. 689, no. 9, pp. 1631-1638. DOI: 10.1016/j.jorganchem.2004.02.015.

12. Wang G.-C., Lu Y.-N., Xiao J., Yu L., Song H.-B., Li J.-Sh., Cui J.-R., Wang R.-Q., Ran F.-X. Synthesis, Crystal Structures and in vitro Antitumor Activities of Some Organoantimony Arylhydroxamates. J. Organomet. Chem., 2005, vol. 690, no. 1, pp. 151-156. DOI: 10.1016/j.jorganchem.2004.09.002.

13. Sharutin V.V., Sharutina O.K., Molokova O.V., Ettenko E.N., Krivolapov D.B., Gubaidullin A.T., Litvinov I.A. Synthesis and Structure of Tetra- and Triarylantimony Oximates. Rus. J. Gen. Chem., 2001, vol. 71, no. 8, pp. 1243-1247. DOI: 10.1023/A:1013220911661.

14. Bruker (2000) SMART. Bruker Molecular Analysis Research Tool, Versions 5.625 Bruker AXS, Madison, Wisconsin, USA.

15. Bruker (2000) SAINT Plus Data Reduction and Correction Program Versions 6.02a, Bruker AXS, Madison, Wisconsin, USA.

16. Doak G.O., Long G.G., Freedman L.D. The Infrared Spectra of Some Phenylsubstituted Pentavalent Antimony Compounds. J. Organomet. Chem., 1965, vol. 4, no. 1, pp. 82-91.

17. Batsanov S.S. [Atomic Radiuses of the Elements]. Rus. J. Inorg. Chem., 1991, vol. 36, no. 12, pp. 3015-3037. (in Russ.)

18. Kopf J., Vetter G., Klar G. Nitrosolate und Nitrosolatokomplexe. III. Darstellung und Struktur von Nitrosolsäurederivaten Organosubstituierter Antimon (V)-, Tellur (IV)-und Jod (III)-Verbindungen. Ztschr. Anorg. und Allg. Chem., 1974, vol. 409, no. 3, pp. 285-298. DOI: 10.1002/zaac.19744090304. 
19. Domasevich K.V., Skopenko V.V., Kempe R., Mohir A.A., Siler I., Hojer Je. [Synthesis, Crystal and Molecular structure of Tetraphenylantimony Complex (V) with 2-Isonitroso-2-(4methylthiazolyl-2)-acetamide]. Rus. J. Inorg. Chem., 1998, vol. 43, no. 2, pp. 246-249. (in Russ.)

20. Domasevitch K.V., Gerasimchuk N.N., Mokhir A. Organoantimony (V) Cyanoximates: Synthesis, Spectra and Crystal Structures. Inorg. Chem., 2000, vol. 39, no. 6, pp. 1227-1237. DOI: 10.1021/ic9906048.

Received 7 December 2017

Удк 546.865+547.1.13+547.304.6+547.53.024+548.312.5

DOI: $10.14529 /$ chem180106

\title{
СИНТЕЗ И СТРОЕНИЕ ß-ИЗАТОКСИМАТА ТЕТРАФЕНИЛСУРЬМЫ
}

\author{
Е.В. Артемьева, О.К. Шарутина \\ Южно-Уральский государственный университет, г. Челябинск, Россия
}

\begin{abstract}
Взаимодействием пентафенилсурьмы с $\beta$-изатоксимом синтезирована ( $\beta$-изатоксимато)тетрафенилсурьма (1). Методом рентгеноструктурного анализа установлено, что атом сурьмы в комплексе (1) имеет искаженную тригонально-бипирамидальную координацию.

Ключевые слова: пентафенилсурьма, $\beta$-изатоксим, дефенилирование, ( $\beta$-изатоксимато)тетрафенилсурьма, молекулярные структуры, рентгеноструктурный анализ.
\end{abstract}

\section{Литература}

1. Schmidbaur, H. Hydrogendicarboxylat-Ionen als Wasserstoffbrückenverknüpfte Chelatsysteme in Organoantimonverbindungen / H. Schmidbaur, K. H. Mitschke // Angew. Chem. - 1971. - V. 83, № 4. - P. 149-150.

2. Синтез и строение аддуктов нитрата тетрафенилсурьмы с азотной кислотой и ацетата тетрафенилсурьмы с уксусной кислотой / В.В. Шарутин, В.С. Сенчурин, О.К. Шарутина и др. // Журн. неорг. химии. - 2008. - Т. 53, № 7. - С. 1194-1198.

3. Синтез и строение 3-гидрокси-4-ацетилфенокситетрафенилсурьмы / В.В. Шарутин, О.К. Шарутина, Е.А. Бондарь и др. // Журн. общ. химии. - 2003. - Т. 73, № 3. - С. 376-379.

4. Синтез и строение кислых сульфатов тетрафенилсурьмы и -фосфора / В.В. Шарутин, А.П. Пакусина, И.В. Егорова и др. // Журн. общ. химии. - 2003. - Т. 73, №. 4. - С. 569-572.

5. Синтез и строение органосульфонатов тетра- и трифенилсурьмы / В.В. Шарутин, О.К. Шарутина, А.П. Пакусина и др. // Коорд. химия. - 2004. - Т. 30, № 1. - С. 15-24.

6. Шарутин, В.В. Синтез и строение ароксидов тетрафенилсурьмы $\mathrm{Ph}_{4} \mathrm{SbOAr}\left(\mathrm{Ar}=\mathrm{C}_{6} \mathrm{H}_{4} \mathrm{C}_{6} \mathrm{H}_{7}\right.$, $\mathrm{C}_{6} \mathrm{H}_{2}\left(\mathrm{Br}_{2}-2,6\right)\left(\right.$ tert-Bu-4), $\left.\mathrm{C}_{6} \mathrm{H}_{3}\left(\mathrm{NO}_{2}\right)_{2}-2,4, \mathrm{C}_{6} \mathrm{H}_{2}\left(\mathrm{Br}_{2}-2,6\right)\left(\mathrm{NO}_{2}-4\right)\right)$ / B.B. Шарутин, О.К. Шарутина, B.C. Сенчурин // Журн. неорг. химии. - 2017. - Т. 62, № 3. - С. 290-295. DOI: 10.7868/S0044457X17030151.

7. Синтез и строение оксиматов тетра- и триарилсурьмы / В.В. Шарутин, О.К. Шарутина, О.В. Молокова и др. // Коорд. химия. - 2002. - Т. 28, № 8. - С. 581-590.

8. Синтез и строение оксиматов тетрафенилсурьмы $\mathrm{Ph}_{4} \mathrm{SbON}=\mathrm{CRR}^{\prime}\left(\mathrm{CRR}^{\prime}=\mathrm{C}_{6} \mathrm{H}_{9}-\mathrm{C}_{6} \mathrm{H}_{9}-2\right.$ и $\left.\mathrm{R}=\mathrm{Ph}, \mathrm{R}^{\prime}=\mathrm{C}(\mathrm{O}) \mathrm{Ph}\right) /$ В.В. Шарутин, О.К. Шарутина, О.В. Молокова и др. // Коорд. химия. 2004. - T. 30, № 8. - C. 596-602.

9. Шарутин, В.В. Синтез и строение салицилальдоксиматов тетра- и трифенилсурьмы / В.В. Шарутин, О.К. Шарутина, О.В. Молокова // Журн. неорг. химии. - 2012. - Т. 57, № 6. - С. $902-$ 907.

10. Шарутин В.В., Шарутина О.К. Синтез и строение оксиматов тетрафенилсурьмы: $\mathrm{Ph}_{4} \mathrm{SbON}=\mathrm{CHR}\left(\mathrm{R}=\mathrm{C}_{6} \mathrm{H}_{4} \mathrm{Br}-2, \mathrm{C}_{6} \mathrm{H}_{4} \mathrm{NO}_{2}-2, \mathrm{C}_{4} \mathrm{H}_{3} \mathrm{~S}\right) /$ V.V. Sharutin, O.K. Sharutina // Коорд. химия. 2017. - T. 43, № 4. - C. 54-59. 


\section{Химия элементоорганических соединений}

11. Synthesis, Crystal Structures and in vitro Antitumor Activities of Some Arylantimony Derivatives of Analogues of Demethylcantharimide / G.C, Wang, J. Xiao, L. Yu et al. // J. Organomet. Chem. - 2004. - V. 689, N 9. - P. 1631-1638.

12. Synthesis, Crystal Structures and in vitro Antitumor Activities of Some Organoantimony Arylhydroxamates / G.C. Wang, Y.-N. Lu, J. Xiao et al. // J. Organomet. Chem. - 2005. - V. 690, № 1. - P. 151-156.

13. Синтез и строение оксиматов тетра- и триарилсурьмы / В.В. Шарутин, О.К. Шарутина, О.В. Молокова и др. // Журн. общ. химии. - 2001. - Т. 71, № 8. - С. 1317-1321.

14. Bruker (2000) SMART. Bruker Molecular Analysis Research Tool, Versions 5.625 Bruker AXS, Madison, Wisconsin, USA.

15. Bruker (2000) SAINTPlus Data Reduction and Correction Program Versions 6.02a, Bruker AXS, Madison, Wisconsin, USA.

16. Doak, G.O. The Infrared Spectra of Some Phenylsubstituted Pentavalent Antimony Compounds / G.O. Doak, G.G. Long, L.D. Freedman // J. Organomet. Chem. - 1965. - V. 4. - № 1. - P. 82-91.

17. Бацанов, С.С. Атомные радиусы элементов / С.С. Бацанов // Журн. неорг. хим. - 1991. T. 36, № 12. - C. 3015-3037.

18. Kopf, J. Nitrosolate und Nitrosolatokomplexe. III. Darstellung und Struktur von Nitrosolsäurederivaten organosubstituierter Antimon (V)-, Tellur (IV)-und Jod (III)-Verbindungen / J. Kopf, G. Vetter, G. Klar // Ztschr. Anorg. und Allg. Chem. - 1974. - V. 409, № 3. - P. 285-298.

19. Домасевич, К.В. Синтез, кристаллическая и молекулярная структура комплекса тетрафенилсурьмы (V) с 2-изонитрозо-2-(4-метилтиазолил-2)- ацетамидом / К.В. Домасевич, В.В. Скопенко, Р. Кемпе и др. // Журн. неорг. хим. - 1998. - Т. 43, № 2. - С. 246-249.

20. Domasevitch, K.V. Organoantimony (V) Cyanoximates: Synthesis, Spectra and Crystal Structures / K.V. Domasevitch, N.N. Gerasimchuk, A. Mokhir // Inorg. Chem. - 2000. - V. 39, № 6. P. $1227-1237$.

Артемьева Екатерина Владимировна - аспирант химического факультета, ЮжноУральский государственный университет. 454080, г. Челябинск, пр. им. В.И. Ленина, 76. E-mail: katriona-art@yandex.ru.

Шарутина Ольга Константиновна - доктор химических наук, профессор, заведующий кафедрой теоретической и прикладной химии, Южно-Уральский государственный университет. 454080, г. Челябинск, пр. им. В.И. Ленина, 76. E-mail: sharutinao@mail.ru.

Поступила в редакцию 7 декабря 20172.

\section{ОБРАЗЕЦ ЦИТИРОВАНИЯ}

Artem'eva, E.V. Synthesis and Structure of Tetraphenylantimony $\beta$-Isatoximate / E.V. Artem'eva, O.K. Sharutina // Вестник ЮУрГУ. Серия «Химия». - 2018. - Т. 1, № 1. C. 48-54. DOI: $10.14529 /$ chem 180106

\section{FOR CITATION}

Artem'eva E.V., Sharutina O.K. Synthesis and Structure of Tetraphenylantimony $\beta$-Isatoximate. Bulletin of the South Ural State University. Ser. Chemistry. 2018, vol. 10, no. 1, pp. 48-54. DOI: 10.14529/chem180106 